\title{
Thereturn of Romeo
}

\author{
Scientists' international mobility and thefuture of research in Europe
}

\section{AnnaRitaMigiaccio\&SjaakPhilipæn}

"O Romeo, Romeo! Wherefore art thou Romeo?"

-William Shakespeare, Romeo and Juliet (Act II, Scene II)

W ho is not familiar with this line from the most well-known love story in literature? Much of its endurance is derived from the name Romeo, which has become a universal symbol of youth, Italy and the passion associated with both. Even when setting his plays in other countries, Shakespeare still reflected on, and drew inspiration from, the social and political situation in medieval Britain, not least because he wanted his English audience to identify with his stories and characters. At that time, 'Romeo' was not only a name, but also a term for young students from Northern Europe who went on a pilgrimage to Rome-and elsewhere in Italy-along a route that became known as the Romean road. The wealth of new ideas that these students brought back from Italian universities and seminars to their home countries was an important factor behind the rapid spread of knowledge across Western Europe, which culminated in the Enlightenment and the creation of modern science (Lyons, 1978). Here, we pursue the idea that Shakespeare's Romeo might have been a scientist.

Today, students-like their medieval predecessors-travel all over the world in search of knowledge and training. Consequently, international networks and exchange programmes for individual scientists are recognized as important tools for maintaining the competitiveness of European science in an increasingly global arena. These programmes rekindle the era of the Romeos in the Middle Ages, but it is not yet clear whether they will have the same impact on Europe's science and research as they did centuries ago. The problem is not the willingness of students to go abroad, but that there is simply too much red tape and too little incentive for many of them to return to Europe. This is a worrying trend not only for science but also for the economy, particularly as Europe needs scores of scientists and engineers if science is to become the motor for economic growth as described by the European heads of state in the Lisbon Agenda (Gannon, 2006).

$\Lambda$ fter the capture of Constantinople by the Turkish army in 1453, many Christian and Jewish scientists and philosophers migrated from the Byzantine kingdom to Italy to work in universities, notably Padua, Bologna and Ferrara. They brought both old and new ideas to Western Europe: not only ancient Greek philosophy and wisdom but also many insights from Arab science, particularly in medicine, mathematics and engineering. This wealth of know ledge attracted many students from all over Europe to Italian universities. In the post-reform Elizabethan society, Romeo no longer meant 'pilgrim to Rome' but became associated with young, mainly medical, students who travelled to or from Italy. It is tempting to think that Shakespeare chose the name Romeo because, at the time of

\section{The problem is not the willingness of students to go abroad, but that there is simply too much red tape and too little incentive for many of them to return to Europe}

Q ueen Elizabeth I, many Londoners either had been Romeos themselves, or had a brother, son or nephew who was studying in Italy. Shakespeare thus established an emotional link between his audience and his hero. It might even have been a way to include the court physicians, who had been Romeos, into the plot of his plays.

This era was also defined by massive changes in how science was studied, particularly biology and medicine. The ideal of the Renaissance $\mathrm{M}$ an-the universal scientist, equally knowledgeable in the arts, philosophy and the natural sciences, and best exemplified by Leonardo da Vinci-was supplemented by the 'modern investigator' who focused on a specific discipline. Similarly, the scholastic approach to science, on the basis of Aristotle's philosophy-the assumption that the laws of the universe could be elucidated through reason alone- became outdated and was replaced by Plato's dialectic - the art of reasoning by question and answer, implying that ideas must be proven through experimentation. During this exciting period of European history, the Romeos exerted the function of 'nemi'-vectors diffusing scientific ideas quickly across the continent, similar to a highly contagious disease.

There are many examples of 'Romeos of excellence' who made great contributions to the progress of science and challenged existing theories proposed by the scientists of the time (see sidebar). As with these outstanding scientists, many other Romeos became visiting fellows, and their vitality and enthusiasm had a fundamental role in creating networks throughout the international scientific community during the sixteenth and seventeenth centuries. They established national scientific societies- 


\section{ROMEOSOF EXCELLENCE}

At theUniversity of Bologna, Niccolò Leoniceno becamefamous for daring to publish experiments that disproved the botanic principles described in Pliny's Natural History. At theturn of thesixteenth century, the English humanist and physician Thomas Linacre- a student of Leoniceno- became professor first at the University of Padua and later at Oxford University, UK, wherehealso becamethe personal physician of King Henry VII and King Henry VIII

The Swiss physician Theophrastus Bombastus von Hohenheim (also known as Paracelsus) also studied under Leoniceno, was the first to lecture in a language other than Latin-in Basel helectured in German - and established the principles of modern pharmacology.

Other RomeosincludeWilliam Harvey, one of the personal physicians to King Charles I, who studied at Padua under Girolamo Fabrizio d'Acquapendente in the early sixteenth century. Harvey's scientific merits included the use of measurements in medical diagnosis. Harvey's greatest scientific contribution - the discovery of theblood circulation system - was followed by that of M arcello M alpighi, who discovered capillaries in the seventeenth century.

Jean Fernel, a French court physician, divided medicineinto physiology, pathology and therapy. Fernel also publicized Girolamo Fracastoro's theory that syphilis was a disease transmitted by sexual contact, which was unknown to Aristotle's medicine. It is hard for us to imagine how revolutionary it must have been at that time to claim that Aristotle did not know everything.

such as the Accademia dei Lincei in Rome, The Royal Society in London and the Académie des Sciences in Paris-which published the first scientific magazines, thus accelerating the spread of knowledge and ideas. At that time, scientists who had made important discoveries were invited to write a letter to be published in the journal of The Royal Society-the term 'letter' is still used today to describe scientific contributions to some journals.

W ith time, the habit of referring to visiting fellows as Romeos faded, but their importance in the development of science did not. Now, as then, ideas and progress travel best when carried by young scientists, and visiting fellows have had an important role in the rapid progress of science since the Second
World War. The enormous success of science and research in the USA convinced many European scientists to work at US universities. For example, the German physicist Theodor Hänsch, who shared the 2005 Nobel Prize in Physics with Roy Glauber and John Hall, spent part of his scientific career at Stanford University in California, USA. Similarly, John Sulston, who received the 2002 Nobel Prize in Physiology or Medicine with Sydney Brenner and Robert Horvitz, was a postdoctoral fellow at the Salk Institute in La Jolla, California, USA.

\section{... ideas and progresstravel best when carried by young scientists, and visiting fellows have had an important rolein the rapid progress of science sincethe Second World War}

Although $\mathrm{H}$ änsch and Sulston eventually returned to their European home countries to continue their work, many other emigrants have not. Of the hundreds of thousands of European students and postdoctoral researchers at US universities, many will stay. Ironically, the departure from their home country was often sponsored by European funding agencies. This 'brain drain'-a term first coined by The Royal Society to describe the flow of highly educated people to North America in the 1950s and 60s-is well documented. Current estimates put the number of European academic graduates living in the USA at more than 400,000 and only $10-15 \%$ contemplate a return (Chu, 2004).

This illustrates the increasing globalization of science, well ahead of other economic sectors. Asian countries, such as India, China and Singapore, are investing massive funds into their research base and have become attractive players in the global market for human potential. The competition for the best and brightest individuals is becoming more intense and, as the USA has shown, many scientists will go-and stay-where they find the best and most productive research environment. Industry is slowly reorganizing its research and development enterprises in such a way that the coordinating teams and headquarters are located in high-cost, advanced nations while the day-to-day collection and processing of data is transferred to low-cost countries (Brower, 2004). These latter countries appreciate the lucrative economic potential of such foreign investments and often support such initiatives both financially and administratively.

$\mathrm{T}$ his point in particular exposes the Achilles' heel of the European socioeconomic system when it comes to attracting educated workers and investment into research and development: the evertightening network of laws, guidelines, rules and regulations, which strangle both entrepreneurial spirit and scientific innovation. European scientists have to battle with bureaucratic procedures that are often unnecessary, ludicrous or incomprehensible. For example, to obtain a licence to create transgenic mice in the $\mathrm{N}$ etherlands, a researcher might be asked to submit a detailed overview of the genetic lines that will be created during the first five years. Any deviation from this plan must be on the basis of solid arguments and requires approval from an official committee. Such procedures, which can be even more stringent in other countries, are obviously out of step with the age of modern biology, in which the policy makers who put such strict regulations in place then expect scientists to perform genome-wide research to strengthen Europe's competitiveness in the global market. O ne can only hope that the pending revision of the European U nion (EU) directive on the protection of animals used for experimental and other scientific purposes (EU, 1986) will not worsen the situation; this would undoubtedly be a further blow for European biomedical research.

\section{European scientists have to battle with bureaucratic procedures that are often unnecessary, ludicrous or incomprehensible...}

Another example is the EU directive on fixed-term contracts (EU, 1999), which aims to protect workers by preventing employers from using successive short-term contracts to avoid permanent employment. Although this is certainly good for employees in many sectors, the directive reduces the flexibility that such contracts offer academic research (Dillon, 2003). This creates problems when research projects do not proceed as planned, because it becomes harder for group leaders or professors to 


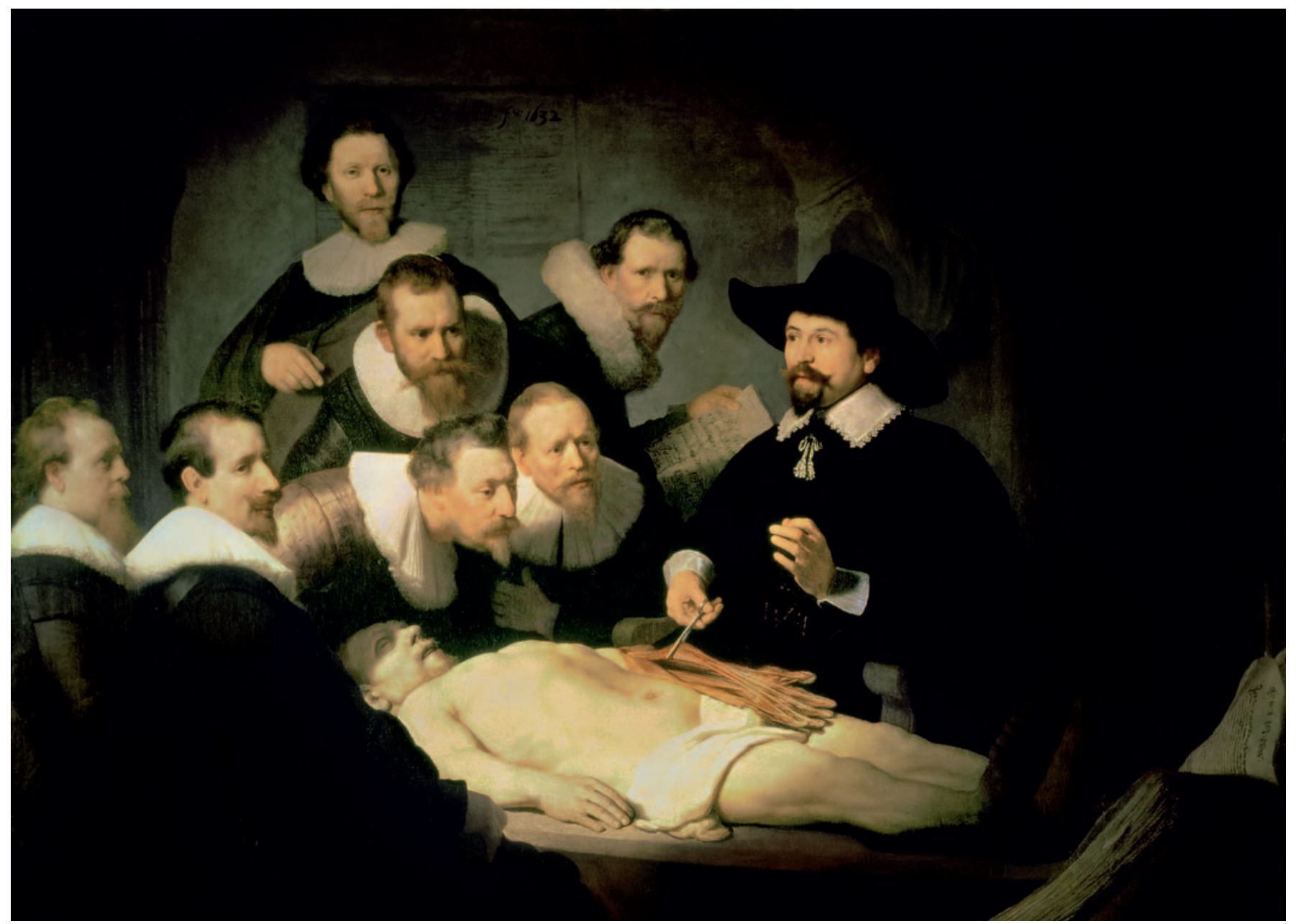

TheAnatomy Lesson of Dr N icolaesTulp, 1632 (oil on canvas), Rembrandt Harmensz. van Rijn (1606-69)/M auritshuis, TheH ague, TheN etherlands/Bridgeman Giraudon. This painting depicts state- of-the-art scientific teaching in the seventeenth century. This year is the 400th anniversary of theartist's birth.

extend a researcher's contract in order to finish a project and move it to publication. By contrast, the flexibility of the US system-and the ease with which contracts can be extended-is one of the reasons why many postdoctoral researchers choose to go there (Breithaupt, 2000).

U nfortunately, the EU 's track record of reducing regulation is not very good; generally, once a guideline is in place, the situation will only get worse. The Framework Programmes (FP) for Research and Technological Development are the EU's main instrument for funding research in Europe. In 2000, the Commission of the European Communities vowed that the much-loathed legal, financial and administrative complexity of FP5 would be substantially simplified in FP6. It is now safe to say that the opposite has happened (Jox, 2003). If the dinosaur that is the EU today does not become more dynamic and enterprising, it will soon be fossilized in its own paper mountain.

Economic developments in agriculture, healthcare and technology rely predominantly on research, and Europe cannot afford to slip further behind in these areas. In a global arena, single nations are too small to make a significant impact, but Europe as a whole-a continent with a rich history in science-certainly has the potential to recreate a competitive research environment. However, this requires action at several levels.

\section{... Europeasa whole-a continent with a rich history in science- certainly has the potential to recreatea competitive research environment}

\begin{abstract}
E irst and foremost, the training of scientists needs to be technically and intellectually sound. The wave of democratization that struck W estern Europe in the 1970s has levelled education programmes from primary schools to universities in many countries. Although breaking down the barriers to higher education and easing access to universities are commendable objectives, they have often gone hand in hand with lowering standards of curricula. This tendency has been strengthened by the policy of some governments to base their funding of universities on the outflow of graduates, rather than the intake of students. Inevitably, universities reacted by reducing the failure rate of students as much as possible. This could have been achieved through a stricter selection process-as seen in most US universitiesbut such a practice would go against the
\end{abstract}


Table1 | Examples of individual fellowships available from European private and public agencies

\begin{tabular}{lll}
\hline Fundingagency & Categories & Length \\
\hline $\begin{array}{l}\text { European M olecular Biology } \\
\text { Organization Fellowship (EU) }\end{array}$ & Postgraduate & Up to 3years \\
\hline MarieCurieFellowship (EU) & Postgraduate & Up to 3years \\
\hline Euratom (EU) & Postgraduate & 1 year \\
\hline European scientific associations & Graduate & Up to 3years \\
(i.e. EHA and theJ. Carreras & Postgraduate & Up to 3years \\
Fellowship Program) & Established investigators & Up to 3years \\
\hline
\end{tabular}

principle that universities should accept anyone who is eligible. The solution was to reduce teaching programmes to the bare essentials, to avoid difficult subjects as much as possible and to decrease practical training. For example, medical students at Erasmus University Rotterdam no longer need to master the principles of enzyme kinetics. Quite obviously, this does not increase the quality of education; instead, it will produce university graduates whose knowledge and experience is insufficient for today's gl obal research labour market.

U niversities should make top-level education their core business again, and policy makers should give them the means to do so. Rather than chopping off the head of anyone who sticks out, they should allow gifted individuals to flourish in an academic environment. In addition, European countries should establish a common university training programme to ease the exchange of professionals between various nations. To this end, the Bologna Declaration of 19 June 1999 calls for the establishment of a competitive European Higher Education Area, and the European Commission (EC) reported on 'Education \& Training 2010' (EC, 2003) to identify common university training across Europe. Although this is a first step in the right direction, the sad fact is that only a handful of European universities are able to offer a high-quality education comparable with that of a top US university.

To make matters worse, the system of research funding in the EU is woefully restrictive. The Framework Programmes represent just a few percent of the total money spent on research and development in Europe; the bulk of the money comes from national funding agencies, each with its own agenda, guidelines, laws and regulations. By contrast, the main US funding bodies- the National Institutes of Health $(\mathrm{NIH})$, the National Science Foundation, the Department of Defense and the Department of Energy-not only have massive budgets to target areas of social, medical or economic relevance, but also provide much more flexibility for researchers, such as allowing them to take their funding from one place to another.

\section{Itis a source of astonishment that theEU pours much moremoney into agriculture than into science}

To be on par with the USA and to become more competitive in light of the emerging scientific powers in Asia, Europe must integrate further both its research and educational systems as well as its funding schemes. The aim should be more mobility and flexibility within the continent, otherwise Europe will continue to lose its best scientists to the USA and Asia. In practice, this integration cannot be enforced by law but must take place through frequent cultural and personal exchanges at all levels: the return of the Romeos. European funding agencies already provide various fellowships for young scientists who want to move abroad (Table 1). A few examples of network programmes that offer senior scientists the opportunity to gain knowledge in a new environment are listed in Table 2.

$T$ his is clearly not enough, as the money from such funding schemes often pays for a one-way trip to the USA. But there are some encouraging developments. In the long term, the newly founded European Research Council (ERC), funded mainly by the EU, might become the European counterpart to the $\mathrm{NIH}$ (Breithaupt, 2004). It will be an independent, pan-European funding agency directed by a Scientific Council that features an impressive list of 22 outstanding European scientists. Ernst-Ludwig Winnacker, current President of the German Research Foundation (DFG; Berlin) and one of Germany's leading biologists, will act as its Secretary General from 2007 to 2009. The high-profile scientists at the helm of the ERC - and its clear mandate to base funding decisions on scientific excellencehold promise that it might attract scientists back from abroad and thus strengthen European science. The first call for proposals, targeting early-stage independent investigators, is expected to go out in early 2007. A total budget of $€ 7.46$ billion is now proposed for 2007-2013; although this might seem small compared with the $2006 \mathrm{NIH}$ budget of US\$15.5 billion for research grants, it is expected that the budget of the ERC will increase significantly once it has proven to be successful.

However, the creation of the ERC is not enough. It is still a source of astonishment that the EU pours much more money into agriculture than into science. The most important goal for the continent must be to develop a research environment that is globally competitive. This will not only help to lure European scientists back from

Table2 | Summary of scientific and didactical exchangeactivities being organized within the University of theEuropean Community (Internationalization)

\begin{tabular}{|c|c|c|c|c|}
\hline Type & Fundingagency & Aim & Categories & Length \\
\hline Bilateral agreements & Individual universities & Research & Graduate and postgraduate & Varies with the agreement \\
\hline $\begin{array}{l}\text { Agreements sponsored by national } \\
\text { research ministries }\end{array}$ & Individual states & Teaching & Postgraduate & Up to 3 years \\
\hline Erasmus & Individual universities & Teaching & Graduate & 3-12 months \\
\hline $\begin{array}{l}\text { European universities' continuing } \\
\text { education network }\end{array}$ & EC & Teaching & Investigators & 3 years \\
\hline $\begin{array}{l}\text { M arieCurie research } \\
\text { training networks }\end{array}$ & EC & Research & Graduate and postgraduate & Up to 3 years \\
\hline
\end{tabular}




\section{Europe must adopt an open-door policy to ease the exchange of scientists within Europe itself, in particular with Eastern Europe}

other continents, but also attract excellent foreign scientists to European research institutions-as was the situation in the nineteenth century when many outstanding US scientists studied at British, French and German universities. Moreover, Europe must adopt an open-door policy to ease the exchange of scientists within Europe itself, in particular with Eastern Europe. Together, these actions-increasing the quality of university education, reducing red tape, and easing the exchange of scientists across the EU and with other continents-could make Europe more attractive again for young Romeos, this time from all over the world. Just as the medieval Romeos helped to make universities in Italy and Northern Europe the world's leading places of research and knowledge, their successors today can do the same-but only if Europe is able to attract them in the first place.
It is too early to say whether the ERC or international exchange programmes will have a marked impact on the scientific competitiveness of Europe. Nevertheless, they are important first steps. As the history of the Romeos teaches us, their effects might last much longer than the memory of any single scientist or network.

\section{REFEREN CES}

Breithaupt $H$ (2000) The flight from European science. EMBO Rep 1: 104-105

Breithaupt H (2004) Beyond an ERC. EM BO Rep 5: $1120-1122$

BrowerV (2004) Going global in R\&D. EM BO Rep 5: 333-335

Chu J (2004) How to plug Europe's brain drain. Time Magazine, 19 Jan

Dillon N (2003) The postdoctoral system under the spotlight. EM BO Rep 4: 2-4

EC (2003) Education \& training 2010: The success of the Lisbon strategy hinges on urgent reforms. CO M (2003)685 final. Brussels, Belgium: European Commission

EU (1986) Council Directive of 24 N ovember 1986 on the approximation of laws, regulations and administrative provisions of the M ember States regarding the protection of animals used for experimental and other scientific purposes (86/609/EEC). Brussels, Belgium: Council of Europe

EU (1999) Council Directive 1999/70/EC of 28 June 1999 concerning the framework agreement on fixed-term work concluded by ETU C, UN ICE and CEEP. Brussels, Belgium: Council of Europe Gannon F (2006) Wanted: a strategy for European science. EMBO Rep 7: 457

Jox R (2003) Red tape frustrates Europe's fundseekers. N ature 424: 605

Lyons AS, Petrucelli RJ (1978) Medicine: An Illustrated H istory. N ew York, NY, USA:

H.N. Abrams

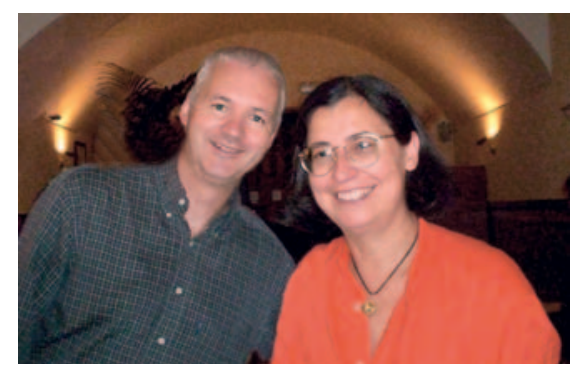

Anna Rita Migliaccio (right) is at the Istituto Superiore di Sanità in Rome, Italy, and at the Department of Pathology, University of Illinois at Chicago, USA.

E-mail: migliar@iss.it

Sjaak Philipsen is in the D epartment of Cell Biology at Erasmus University Medical Center in Rotterdam, The Netherlands.

E-mail:j.philipsen@erasmusmc.nl

doi:10.1038/sj.embor.7400845 